\title{
KEBENARAN HUKUM PERSPEKTIF FILSAFAT HUKUM
}

\author{
Beniharmoni Harefa \\ Mahasiswa Pascasarjana FH UGM Yogyakarta \\ Email : beni_harefa@yahoo.com
}

\begin{abstract}
ABSTRAK
Memahami kebenaran hukum dari sisi filsafat hukum, harus diawali dengan memahami pengertian dan tujuan hukum itu sendiri. Hukum secara sederhana dapat diartikan sebagai sekumpulan aturan, kaedah yang berasal dari nilai-nilai yang kemudian menjelma menjadi norma. Kehadiran hukum sangat dibutuhkan dalam menciptakan ketertiban di dalam kehidupan sosial manusia tersebut, itulah yang menjadi salah satu tujuan hukum. Dikenal tiga teori dalam menentukan kriteria kebenaran. Teori korespondensi, teori koherensi atau konsistensi, dan teori pragmatis. Kesimpulan, kebenaran hukum perspektif filsafat hukum, kembali kepada paradigma/ teori apa yang digunakan. Keyakinan atau kepercayaan hukum apa yang dianut oleh seseorang akan membawanya kepada jawaban akan kebenaran hukum yang ia percayai. Maka untuk menuntun seseorang kepada kebenaran hukum yang sesungguhnya, dibutuhkan ilmu. Sehingga kebenaran hukum yang dicapai adalah kebenaran yang mutlak/ absolut.
\end{abstract}

Kata Kunci : Kebenaran Hukum, Filsafat Hukum

\begin{abstract}
Understanding the legal validity of the philosophy of law, must begin by understanding the sense and purpose of the law itself. The law can be interpreted simply as a set of rules, rules derived from the values which are then transformed into the norm. The presence of the law is needed to establish order in the human social life, that is the one purpose of the law. Known three theories in determining criterion of truth. Correspondence theory, the theory of coherence or consistency, and the pragmatic theory. In conclusion, the truth of the law of legal philosophy perspective, back to the paradigm / theory of what is used. Confidence or trust what the law adopted by someone will take him to the answers to the legal truth that he trusted. Then to lead a person to the truth of the real law, it takes knowledge. So that the truth of law achieved is the absolute truth / absolute.
\end{abstract}

Keywords : Truth of Law, Philosophy of Law

\section{Pendahuluan}

Berbicara tentang kebenaran sesuatu, tidak terlepas dari pengertian dan fungsi dari sesuatu yang akan dicari kebenarannya itu (Inu K Syafii, 2005:59). Demikian halnya berbicara tentang kebenaran hukum, maka tidak terlepas dari pengertian dan fungsi dari hukum itu sendiri.

Pengertian hukum menurut Soedikno Mertokusumo adalah 
keseluruhan

kumpulan peraturan-peraturan atau kaedahkaedah dalam suatu kehidupan bersama (Sudikno M, 2003:40). Hukum secara umum juga dapat diartikan sebagai keseluruhan peraturan tentang tingkah laku yang berlaku dalam suatu kehidupan bersama, yang dapat dipaksakan pelaksanaannya dengan adanya sanksi.

Montesquieu dalam bukunya The Spirit of Laws, menyampaikan hukum secara umum dapat diartikan sebagai hubungan pasti yang berasal dari sifat dasar segala sesuatu. Dalam pengertian ini berarti bahwa semua wujud memiliki hukumnya (Montesquieu,2007:88).

Tuhan memiliki hukumnya, dunia material memiliki hukumnya, binatang memiliki hukumnya, manusiapun memiliki hukumnya sendiri. Dalam kaitannya dengan yang akan dibahas tentunya pengertian yang disampaikan oleh Montesquieu akan dibatasi dalam pengertian hukum yang dimiliki oleh manusia.

Kendati hingga saat ini belum ada pengertian yang baku akan defenisi hukum yang sempurna, namun hukum secara sederhana dapat diartikan sebagai sekumpulan aturan, kaedah yang berasal dari nilai-nilai yang kemudian menjelma menjadi norma. Nilai-nilai yang terkandung dalam hukum, tentunya sudah sesuai dengan nilai moral dan etika yang ada dan diakui keberadaannya di dalam kehidupan manusia.

Sejauh ini dengan melihat secara singkat pengertian dan penjelasan di atas, sementara disimpulkan bahwa hukum tentunya berasal dari nilainilai yang dianggap benar di dalam kehidupan manusia.
Tulisan ini hendak membahas kebenaran hukum, ditinjau dari perspektif filsafat hukum. Maka sebelum mengkaji kebenaran hukum, tentunya harus dipahami apa yang menjadi tujuan hukum.

\section{Tujuan Hukum}

Lalu apa tujuan diciptakannya hukum ? Soetandyo Wignjosoebroto mengatakan apabila hukum sudah dikonsepkan sebagai institusi atau gejala sosial yang empiris yang termanifestasi dalam tindakan/ aksi serta interaksi warga masyarakat dalam kehidupan sehari-hari, maka hukum bertujuan untuk mengatur kehidupan manusia dalam masyarakat (Soetandyo Wignjosoebroto,2002:116).

$$
\text { Ditegaskan oleh Satjipto }
$$

Rahardjo bahwa hukum ada untuk manusia, hukum itu tidak ada untuk hukum itu sendiri. Hukum adalah suatu institusi yang bertujuan mengantarkan manusia kepada kehidupan yang adil, sejahtera dan membuat manusia bahagia (Satjipto Rahardjo,2010:33). Dalam rangka memenuhi kebutuhan hidupnya, seseorang manusia membutuhkan manusia lainnya. Manusia tidak dapat hidup sendiri (manusia makhluk sosial) (Aabied,2012:112).

Kehadiran hukum sangat dibutuhkan dalam menciptakan ketertiban di dalam kehidupan sosial manusia tersebut. Hal ini dimaksud untuk menghindari terjadinya konflik antara manusia yang satu dengan manusia lainnya. Sedikit mengenai konflik, konflik itu muncul, pada saat manusia berinteraksi dengan manusia lainnya di dalam kehidupan bermasyarakat (sosial), Manusia mempunyai kepentingan yang berbeda-beda, maka dalam 
memenuhi kepentingannya, rentan menimbulkan pertentangan dengan manusia lainnya (conflict of interest) yang berujung pada kehancuran. Oleh sebab itu, diperlukan hukum yang mengatur agar tercipta ketertiban.

Kembali pada tujuan hukum, dalam pembahasan mengenai tujuan hukum, Thomas Aquinas mengemukakan 4 (empat) macam hukum, yaitu lex eterna, lex naturalis, lex divina dan lex humana (Peter Mahmud Marzuki,2010:104). Lex eterna merupakan suatu aturan yang menguasai alam semesta melalui kehendak Allah sesuai dengan kebijaksanaanNya. Semua makhluk berada dalam kerangka tujuan lex eterna dan manusia mempunyai suatu tujuan tertentu karena manusia merupakan makhluk rasional.

Lex naturalis, menurut Thomas Aquinas, tidak terlepas dari partisipasi makhluk rasional dalam lex eterna. Lex naturalis inilah yang akan mengarahkan aktivitas manusia melalui aturan-aturan dasar dalam hidupnya. Masih menurut Thomas Aquinas, lex divina yaitu pedomanpedoman dari Allah untuk mengarahkan bagaimana seyogianya manusia bertindak. Terakhir, lex humana adalah aturan-aturan yang berasal dari pemerintah atau aturanaturan yang dibuat oleh manusia.

Aturan-aturan ini dibuat dengan menggunakan kekuatan nalar yang dimiliki oleh manusia. Dari pembagian hukum yang dikemukakan Aquinas, terlihat bahwa tujuan hidup manusia menurut Aquinas, bukan hanya untuk mencapai kebahagiaan duniawi belaka, melainkan untuk mendapatkan kebahagiaan kekal sebagai tujuan bersifat supernatural. Secara sederhana Aquinas hendak mengatakan bahwa hukum bertujuan untuk mengantarkan manusia kepada kebahagiaan kekal.

Namun apakah sesederhana itu dalam memahami arti dan fungsi hukum itu sendiri. Apakah nantinya pengertian dan fungsi hukum yang telah disampaikan di atas tidak terjebak pada pengertian dan fungsi yang dogmatik semata. Pertanyaan ini yang kemudian akan dijawab secara filosofis oleh filsafat hukum.

Kembali pada apa yang hendak dibahas dalam tulisan ini, yakni kebenaran hukum jika ditinjau dari filsafat hukum. Apa yang dimaksud dengan filsafat hukum ? memang tidak mudah untuk mendefenisikan apa itu filsafat hukum (Dominikus Rato,2011:2).

\section{Filsafat Hukum}

Theo Huijbers mengatakan bahwa pokok persoalan filsafat hukum bukanlah quid iuris, melainkan quid ius. Sebagai quid iuris hukum berorientasi pada dan sebagai hukum positif yaitu hukum yang berlaku dan sedang berlaku saja. Sedangkan quid ius, hukum berorientasi sebagai sesuatu yang substantif dan esensial, inilah yang kemudian teba telaah filsafat hukum (Theo Huijbers,1995:76).

H.L.A. Hart, berpendapat bahwa filsafat hukum adalah karya pikir bersama antara filsafat moral, filsafat politik, dan bahasa. Sebagai hasil karya filsafat moral, filsafat hukum membahas konsep-konsep hukum tentang rasa bersalah, kesalahan, niat, dan tanggung jawab yang merupakan issue sentral dalam hukum terutama ketika hukum menekankan konsepkonsep di atas dalam pikiran dan perbuatan (H.L.A. Hart,2009). 
Mempelajari filsafat hukum tentunya akan membawa seseorang pada apa yang dimaksud mengenai hukum itu, dengan sebenar-benarnya dan sedalam-dalamnya. Plato dalam tulisannya Andre Ata Ujan, menyampaikan bahwa seorang filsuf (orang yang ahli filsafat), tidak pernah berhenti mencari dan menemukan kebenaran (searching for truth) dan membangun keadilan (to built justice) (Andre Ata Ujan,2009:17-18).

Bahkan kebenaran dan keadilan, hasil pemikiran para filsuf sebelumnya, pun tidak luput dari sikap kritik filsafat mereka, sebab dalam filsafat tidak ada kebenaran yang final. Demikian halnya dengan filsafat hukum, filsafat hukum harus berupaya mencari dan menemukan hakekat hukum secara radikal (sampai ke akar-akarnya), secara sistematis, rasional, dan metodis. Filsafat hukum berupaya untuk menemukan jawaban terdalam dari sebuah objek formalnya, yaitu hukum.

Darji Darmodiharjo dan Shidarta, mengungkapkan bahwa filsafat hukum adalah filsafat tingkah laku dan etika, yang mempelajari hakekat hukum secara filosofis. Hukum dikaji secara mendalam sampai kepada inti atau dasarnya yang disebut dengan hakekat (Darji Darmodiharjo dan Shidarta, 2004:11).

J.J.H. Bruggink dalam bukunya Otje Salman dan Anton F. Susanto, mengatakan bahwa filsafat hukum adalah induk dari semua disiplin yuridik. Karena filsafat hukum membahas masalah-masalah yang paling fundamental yang timbul dalam hukum (Otje Salman dan Anton F. Susanto,2004:64). Ditambahkannya, oleh karena kefundamentalannya masalahmasalah hukum yang hendak dibahas itu, sehingga oleh manusia tidak terpecahkan. Oleh karena masalahnya melampaui kemampuan berpikir manusia.

Filsafat hukum akan merupakan kegiatan yang tidak pernah berakhir, karena mencoba memberikan jawaban pada pertanyaanpertanyaan abadi. Pertanyaan itu tentunya adalah pertanyaan yang terhadapnya, hanya dapat diberikan jawaban yang menimbulkan banyak pertanyaan baru.

Maka dalam menjawab pertanyaan bagaimana kebenaran hukum perspektif filsafat hukum ini nantinya, kiranya akan membawa kita pada wilayah yang semakin menimbulkan pertanyaanpertanyaan baru tentang hukum. Kita semakin tidak akan berhenti dan puas pada jawaban atas pertanyaan kebenaran hukum perspektif filsafat hukum.

Bahkan jawaban akan pertanyaan tentang kebenaran inilah yang kemudian nantinya, akan membawa kita berjalan jauh, menyusuri pengertian mengenai hukum yang sedalam-dalamnya sampai ke akarakarnya, itulah filsafat. Maka untuk itu pengertian kebenaran juga harus dipahami.

\section{Pengertian Kebenaran}

Maksud dari hidup ini adalah untuk mencari kebenaran. Tentang kebenaran ini, Plato pernah berkata: "Apakah kebenaran itu? lalu pada waktu yang tak bersamaan, bahkan jauh belakangan Bradley menjawab; "Kebenaran itu adalah kenyataan", tetapi bukanlah kenyataan (das sollen) itu tidak selalu yang seharusnya (das sein) yang terjadi. 
Kenyataan yang terjadi bisa saja berbentuk ketidakbenaran (keburukan). Jadi ada 2 pengertian kebenaran, yaitu kebenaran yang berarti nyata-nyata terjadi di satu pihak, dan kebenaran dalam arti lawan dari keburukan (ketidakbenaran) (Marwadi, 2013).

Dalam bahasan ini, makna "kebenaran" dibatasi dalam makna "kebenaran hukum". Apa yang dewasa ini kita pegang sebagai kebenaran hukum, mungkin suatu saat akan hanya pendekatan kasar saja dari suatu kebenaran yang lebih sejati lagi dan demikian seterusnya.

Hal ini tidak bisa dilepaskan dengan keberadaan manusia yang transenden,dengan kata lain, keresahan mencari kebenaran hukum berkaitan erat dengan hasrat yang ada dalam diri manusia yang selalu ingin mencari kebenaran yang sesungguhnya. Dari sini terdapat petunjuk mengenai kebenaran yang trasenden, artinya tidak berhenti dari kebenaran hukum itu saja, namun terdapat kebenaran diluar jangkauan manusia. Utamanya untuk mencari kebenaran hukum secara filosofis.

Dikenal ada beberapa teori dalam menentukan kriteria kebenaran. Teori korespondensi (yakni persamaan dengan fakta), teori koherensi atau konsistensi, dan teori pragmatis

(Harold

Titus,dkk,2007:105). Pertama, teori korespondensi adalah paling diterima secara luas oleh kelompok realis. Menurut teori ini, kebenaran adalah kesetiaan kepada realita obyektif (fidelity to objective reality).

Kebenaran adalah persesuaian antara pernyataan tentang fakta dan fakta itu sendiri, atau antara pertimbangan (judgement) dan situasi dimana pertimbangan itu berusaha untuk melukiskan, karena kebenaran mempunyai hubungan erat dengan pernyataan atau pemberitaan yang kita lakukan tentang sesuatu (Jujun S. Sumiasumantri,2000).

Secara sederhana dapat disimpulkan bahwa berdasarkan teori korespondensi suatu pernyataan adalah benar jika materi hukum yang dikandung pernyataan itu berkorespondensi (berhubungan) dengan obyek yang dituju atau diatur oleh hukum tersebut. Misalnya "jika seorang melakukan pencurian maka orang tersebut akan dihukum, agar menimbulkan efek jera sehingga orang lain tidak melakukan pencurian lagi dan kehidupan menjadi tertib".

Materi hukum itu adalah benar, sebab sebagaimana kita ketahui bahwa hukum ada dan berfungsi untuk mengatur tingkah laku manusia, agar tidak saling menghacurkan sebagaimana dikemukakan Thomas Hobbes : homo homini lupus (manusia adalah serigala bagi yang lain). Sehingga dengan adanya hukum tercipta suatu ketertiban dan kedamaian yang menuju pada kesejahteraan manusia itu sendiri.

Sekiranya ada orang lain yang mengatakan bahwa "pencuri itu tidak dapat dihukum, meskipun telah terbukti" maka tentu saja, pernyataan itu adalah tidak benar. Sebab di dalam hukum diatur mengenai apa yang boleh dilakukan dan apa yang tidak boleh dilakukan. Pencurian merupakan perbuatan yang tidak boleh dilakukan atau dilarang oleh hukum. Oleh sebab itu, seorang pencuri yang telah terbukti melakukan pencurian harus dihukum agar timbul efek jera dan 
menciptakan ketertiban di dalam kehidupan masyarakat.

Dalam hal ini maka secara faktual "setiap orang yang bersalah dapat dihukum, dengan berdasarkan pembuktian, guna menciptakan kedamaian dan ketertiban di dalam kehidupan manusia".

Menurut teori koresponden, ada atau tidaknya keyakinan tidak mempunyai hubungan langsung terhadap kebenaran atau kekeliruan. Kekeliruan itu tergantung kepada kondisi yang sudah ditetapkan atau diingkari. Jika sesuatu pertimbangan sesuai dengan fakta, maka pertimbangan ini benar, jika tidak, maka pertimbangan itu salah.

Dalam wilayah kebenaran hukum berdasarkan teori korespondensi, kesesuaian putusan hakim dengan kebenaran fakta-fakta hukum sangat diutamakan. Kebenaran legalitas, artinya penerapan hukum hukum terhadap sebuah perkara didasarkan pada fakta-fakta hukum yang terdapat pada peristiwa yang terjadi. Teori kebenaran korespondensi mengutamakan kepastian hukum (asas legalitas).

Teori yang kedua tentang kebenaran adalah teori koherensi. Berdasarkan teori ini suatu pernyataan dianggap benar bila pernyataan itu bersifat koheren atau konsisten dengan pernyataanpernyataan sebelumnya yang dianggap benar, artinya pertimbangan adalah benar jika pertimbangan itu bersifat konsisten dengan pertimbangan lain yang telah diterima kebenarannya, yaitu yang koheren menurut logika.

Misalnya, bila kita menganggap bahwa "semua manusia pasti akan mati" adalah suatu pernyataan yang benar, maka pernyataan bahwa "si
Budi adalah seorang manusia dan si Budi pasti akan mati" adalah benar pula, sebab pernyataan kedua adalah konsisten dengan pernyataan yang pertama.

Kelompok idealis, seperti Plato juga filsuf-filsuf modern seperti Hegel, Bradley dan Royce memperluas prinsip koherensi ini. Dengan begitu maka tiap-tiap pertimbangan yang benar dan tiaptiap sistem kebenaran yang parsial bersifat terus menerus dengan keseluruhan realitas dan memperolah arti dari keseluruhan tersebut. Meskipun demikian perlu lebih dinyatakan dengan referensi kepada konsistensi faktual, yakni persetujuan antara suatu perkembangan dan suatu situasi lingkungan tertentu terhadap teori kebenaran ini.

Dikaitkan dengan kebenaran hukum, teori koherensi diimplementasikan dalam tataran ius constituendum, (ide-ide hukum) yang kesesuaian dengan realitas perilaku masyarakat. Kebenaran hukum yang hendak dipenuhi dalam hal ini adalah aspek keadilan yang diutamakan.

Rasa keadilan untuk setiap orang atau kelompok sangat variatif, oleh sebab itu menggunakan teori ini secara mutlak untuk mengungkapkan kebenaran hukum, rasanya tidak mungkin. Karena apa yang dirasakan adil, belum tentu sesuai dengan kepastian dan kemanfaatan hukum.

Teori yang ketiga, yakni teori pragmatik. Dicetuskan oleh Charles S. Peirce dalam sebuah makalah berjudul "How to Make Ideals Clear". Teori ini kemudian dikembangkan oleh beberapa ahli filsafat yang kebanyakan adalah berkebangsaan Amerika yang menyebabkan filsafat ini sering dikaitkan dengan filsafat 
Amerika. Ahli-ahli filsafat ini di antaranya adalah William James, John Dewey, George Hobart Mead, dan C.I. Lewis.

Pragmatisme menantang segala otoritanianisme, intelektualisme dan rasionalisme. Bagi mereka yang menganut pragmatisme, ujian terhadap kebenaran adalah manfaat (utility), kemungkinan dikerjakan (workability) atau akibat yang memuaskan. Sehingga dapat dikatakan bahwa pragmatisme adalah suatu aliran yang mengajarkan bahwa yang benar ialah apa yang membuktikan dirinya sebagai benar dengan perantaraan akibat-akibatnya yang bermanfaat secara praktis. Pegangan pragmatis adalah logika pengamatan dimana kebenaran itu membawa manfaat bagi hidup praktis (Harun Hadiwijono,1990) dalam kehidupan manusia.

Dikaitkan dengan kebenaran hukum, menggunakan teori pragmatis maka kebenaran hukum berhubungan dengan kemanfaatan hukum. Oleh karena itu, dalam perspektif kebenaran pragmatis tidak berorientasi pada sebuah proses atau suatu peristiwa hukum tetapi hasil dari proses atau peristiwa hukum itu. Sesuatu dikatakan benar apabila mempunyai manfaat bagi kehidupan umat manusia. Apa yang dirasakan bermanfaat itulah hukum yang sebenarnya. Lagi-lagi ini tidak bisa digunakan secara mutlak dalam mencari dan mengungkapkan kebenaran hukum.

\section{Kebenaran Hukum Persepektif Filsafat Hukum}

Kembali pada apa yang sedang dibahas mengenai kebenaran hukum perspektif filsafat hukum, apabila ketiga teori kebenaran itu dikaitkan dengan kebenaran hukum, maka akan sulit untuk menentukan kriteria kebenaran apa yang digunakan dalam menentukan kebenaran hukum. Para filsuf dengan berbagai alur pemikiran tidak dapat bersatu dalam menentukan kriteria kebenaran apa yang digunakan dalam menentukan kebenaran hukum. Namun paradigma seseoranglah yang menentukan sesuatu itu benar, karena kebenaran itu bersifat subjektif dan tentatif (Dominikus Rato,Op.Cit:12). Kebenaran yang dianut seseorang menuntunnya untuk mencari dan menemukan serta meyakinkan dia tentang sesuatu yang benar itu.

Berbicara mengenai apakah hukum itu benar ada? dari mana datangnya hukum? untuk apa ada hukum? siapa yang berwenang membuat hukum? mengapa orang tunduk pada hukum ? pertanyaanpertanyaan itu yang akan membawa orang berpikir tentang hukum secara khusus dan mendalam tentang hakekat hukum. Jawaban atas pertanyaan di atas bukan saja membawa orang pada satu pengertian tentang hakekat hukum, melainkan membawa pada berbagai pemikiran, keyakinan atau kepercayaan tentang hal-hal mengenai hukum.

Jawaban atas pertanyaan di atas dapat membawa pada keyakinan, pedoman atau orientasi berpikir tentang hukum. Sehingga kemudian membentuk paradigma, dan paradigma ini menjadi pegangan, pedoman, panduan : berpikir, berkata dan berbuat atau orientasi dasar untuk mengembangkan keyakinan dan kepercayaan tentang hukum.

Lalu, jika kemudian kebenaran hukum dilihat dari pengertian dan 
fungsi hukum itu sendiri, maka dapat disimpulkan. Pertama, apakah benar hukum itu merupakan sekumpulan peraturan-peraturan atau kaedahkaedah dalam suatu kehidupan bersama, maka benar hukum merupakan kumpulan aturan. Kedua, apakah benar fungsi hukum itu adalah untuk mengatur kehidupan manusia maka jawabannya benar. Kendati memang harus ditegaskan bahwa hukum itu ada untuk manusia bukan manusia ada untuk hukum.

\section{Kesimpulan}

Menjawab pertanyaan bagaimana kebenaran hukum perspektif filsafat hukum, maka menggunakan ketiga teori kebenaran yang ada, yakni kebenaran koherensi, korespondensi, pragmatis. Jawaban sederhana yang disampaikan oleh penulis, kebenaran hukum persepektif filsafat hukum, tentunya kembali kepada paradigma apa yang digunakan. Keyakinan atau kepercayaan hukum apa yang dianut oleh seseorang akan membawanya kepada jawaban akan kebenaran hukum yang ia percayai.

Kebenaran yang dianut seseorang menuntunnya untuk mencari dan menemukan serta meyakinkan dia tentang sesuatu yang benar itu. Oleh karena itu diperlukan ilmu untuk membawa manusia menuju kebenaran absolut.

Menurut Sudjito, ilmu merupakan institusi pencarian kebenaran. Ilmu bila dikejar terus akan mentok pada keimanan. Antara iman dan ilmu tidak ada pemisah. Ilmu tanpa iman sama dengan omong kosong. Iman merupakan dasar ilmu (Sudjito, 2013). Oleh karena itu, maka untuk menuntun seseorang kepada kebenaran hukum yang sebenarnya diperlukan ilmu, sehingga kebenaran hukum yang dicapai adalah kebenaran yang mutlak/ absolut.

\section{Daftar Pustaka :}

Aabied, Hakikat Manusia, Nusantara Sentosa, Jakarta, 2012.

Andre Ata Ujan, Filsafat Hukum, Membangun Hukum Membela Keadilan, Kanisius, Yogyakarta, 2009.

Darji Darmodiharjo dan Shidarta, Pokok-pokok Filsafat (Apa dan Bagaimana Filsafat Hukum Indonesia), Gramedia Pustaka Utama, Jakarta, 2004.

Dominikus Rato, Filsafat Hukum (Mencari, Menemukan dan Memahami Hukum), LaksBang Justitita, Surabaya, 2011.

Harun Hadiwijono, Sari Sejarah Filsafat Barat II, Kanisius, Yogyakarta, 1990.

H.L.A.Hart., Hukum, Kebebasan, dan Moralitas, Genta Publising, Yogyakarta, 2009.

Inu Kencana Syafi'i, Filsafat Kehidupan (Prakata),Bumi Aksara, Jakarta 2005.

Jujun S. Sumiasumantri, Filsafat Ilmu,Sebuah Pengantar Populer, Pustaka Sinar Harapan, Jakarta, 2000.

Montesquieu, The Spirit of Laws : Dasar-Dasar Ilmu Hukum dan Ilmu Politik, Nusamedia, Bandung, 2007.

Otje Salman dan Anton F. Susanto, Teori Hukum (Mengingat, Mengumpulkan dan Membuka Kembali), Refika Aditama, Bandung, 2004.

Peter Mahmud Marzuki, Pengantar Ilmu Hukum, Kencana Prenada Media Grup, 2010.

Titus, Harold H., dkk., Living Issues in Philosophy, Terj. H. M. Rasyidi, 
Persoalan-Persoalan Filsafat, Bulan Bintang, Jakarta, 2007.

Theo Huijbers, Filsafat Hukum, Kanisius, Yogyakarta, 1995.

Satjipto Rahardjo, Hukum Progresif: Sebuah Sintesa Hukum Indonesia, Genta Publishing, Yogyakarta, 2010.

Soetandyo Wignjosoebroto, Hukum (Paradigma, Metode dan Dinamika Masalahnya), ELSAM, Jakarta, 2002.

Sudjito bin Atmoredjo, Sari Kuliah : Filsafat Ilmu Hukum, Program S3 Ilmu Hukum, Universitas Gadjah Mada, Yogyakarta

Sudikno Mertokusumo, Mengenal Hukum : Suatu Pengantar, Liberty, Yogyakarta, 2003.

Internet :

Mawardi, Kebenaran Dalam Perspektif Filsafat Ilmu. http://mawardiumm.wordpress.c om/2008/06/02/kebenarandalam-perspektif-filsafat-ilmu/ diakses pada 06 Oktober 2013.

Yanluamohdar, Kebenaran Hukum Dalam Perspektif Pengetahuan Hukum, http://yanluamohdar2010.blogsp ot.com/2013/05/kebenarandalam-perpektif pengetahuan.html/ diakses pada 08 Oktober 2013. 